\section{BLAST DOOR AND ENTRYWAY DESIGN AND EVALUATION}

by

David W. Hyde, Sam A. Kiger

Structures Laboratory

DEPARTMENT OF THE ARMY

Waterways Experiment Station, Corps of Engineers PO Box 631

Vicksburg, Mississippi 39180

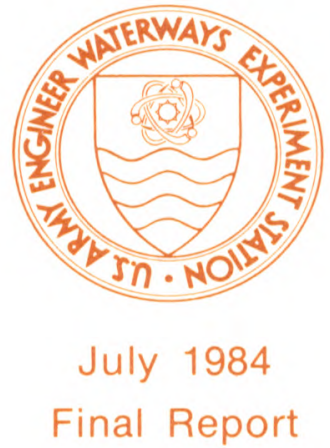

Approved For Public Release; Distribution Unlimited

UNIVERSITY OF ILLINOIS

LIBRARY

AT URBANA-CHAMPAIGN

ENGINEERING

\section{Prepared for Federal Emergency Management Agency} Washington, DC 20472

Under Interagency Agreement No. El

UNIVERSITY OF MICHIGAN 